\title{
Drought and disaster in a revolutionary age: colonial Antigua during the American Independence War
}

\begin{abstract}
The American War of Independence (1775-1783) spelled crisis for the British West Indies. Trade embargos between rebelling and loyal territories, losses to American pirates and hostilities with other European states left the Crown's tropical Atlantic colonies short of the imported supplies that normally sustained their populations and commerce. Historians have studied the dynamics and consequences of these developments in considerable detail, at both regional and local scales, but have tended to focus on economic, social and political dimensions of the subject matter. Although some investigations have highlighted that climate variability compounded agricultural and subsistence problems in certain locations, the role of climate has rarely been subject to the same level of scrutiny. The present paper addresses this theme by focusing on the Lesser Antillean island of Antigua and the severe drought which gripped the colony during the war period. Through extensive analysis of original, largely unpublished archival sources, the implications of deficient rainfall for human livelihoods, fiscal stability and governmental crisis management are examined. By supplementing findings with evidence from other episodes of warfare which coincided with extreme climate phenomena in the late 1700s and early 1800s, it is argued that successive years of drought were pivotal in defining the severe human and economic losses sustained in Antigua during the American independence conflict. The critical agency of this weather event must, however, be understood as the product of its dynamic interaction with the precarious backdrop of a colonial regime under profound socio-economic and geopolitical stress.
\end{abstract}

\section{Introduction}

In early June 1777, the second battalion of King George III's $60^{\text {th }}$ Regiment made a desperate plea for aid. Word was sent to the legislature of Antigua - the British West Indian colony where the battalion was stationed - that the infantrymen could scarcely feed themselves due to inflated food prices. Indeed, their commanding officers believed that if the soldiers had not been issued with an advancement of their salaries, 'many must inevitably have died thro' want'. ${ }^{1}$ This was no state for the troops to be in. Britain was embroiled in an armed struggle to retain control of its North American territory. Meanwhile, the threat of interstate warfare in Caribbean waters was mounting. So it was that the troops' appeal prompted decisive action. By August, the men had been awarded a pay rise, as well as a special allowance of $£ 165$ for purchasing supplies. But, within two months these additional resources too were exhausted and another call for aid was made. This time, the Antiguan administration was unable to assist, for the public treasury was empty. Fearing that the troops might starve, Sir William Matthew Burt, governor of the island, supplied $£ 100$ worth of food at his own expense. ${ }^{2}$

Over the next 18 months, the state of affairs improved little. Drawing on the meagre tax revenues being collected at the time, local government eventually reimbursed Burt and resumed its support of the King's troops. Yet, in April 1779-by which time over $£ 800$ had been spent on emergency rations - the soldiery remained in a 'piteous Condition'. ${ }^{3}$ The cause was now not just hunger, but also a severe lack of drinking water. The only solution was to hire a private contractor to supply water at a rate of $£ 4$ a day. ${ }^{4}$ Ultimately, it proved that such

\footnotetext{
${ }^{1}$ CO152/56, Petition of the $60^{\text {th }}$ Regiment, June 1777. See n. 5 for an explanation of the manner in which archival sources are cited in this paper.

${ }^{2}$ CO152/57, Gov. Burt to Lord Germain, 1 Nov 1777.

${ }^{3}$ CO152/59, T. Jarvis and R. Burton to Gov. Burt, 30 Apr 1779.

${ }^{4}$ Ibid.
} 
expenses were also unsustainable; within weeks the public treasury was declared bankrupt once more.

How could it be that the $60^{\text {th }}$ Regiment, Antigua's first line of internal defence, became exposed to such persistent privations? What was causing the prices of everyday necessities to soar? And why was a once flourishing colonial economy, founded upon the multimillionpound sugar industry, now so unstable? The conventional answer to these questions is geopolitics. From 1775, the severance of commercial relations with the rebelling North American colonies and conflict with other imperial powers resulted in profound subsistence and economic emergencies throughout the British West Indies. In the case of Antigua, however, there was another decisive force at play: intense and prolonged drought. The present paper draws on a range of primary archives - principally plantation and government records - to scrutinise the manifold societal consequences of this weather event and to explore its role in defining local experiences of the war period. ${ }^{5}$ In this way, the paper seeks to illustrate how a climate history lens can afford a novel perspective on this period of crisis. ${ }^{6}$

Within the sub-discipline of climate history, the colonial period has come to represent a significant and dynamic focus of study. ${ }^{7}$ The Caribbean is a region of growing interest and has been the subject of several distinguished publications over the past decade. Matthew Mulcahy and Stuart Schwartz, for example, have presented wide-ranging hurricane histories, broaching themes as varied as colonial conceptualisations of the storms, their influence on imperial politics and institutional responses to the disasters they provoked. ${ }^{8}$ Meanwhile, Sherry Johnson has re-narrated a number of landmark socio-political events in the region's mid-late eighteenth century past, emphasising their connection with crises featuring extreme weather phenomena - crises which she argues were especially frequent during this period of climatic warming. A key element of Johnson's work are detailed, empirically-rich narratives of how disasters unfolded in their socio-political and ecological contexts, illustrating the ways adverse weather can act as a trigger for political and social change. ${ }^{9}$

\footnotetext{
${ }^{5}$ Unpublished documentary sources (all consulted in the UK) will henceforth be referenced using the following codes to denote collection name and location: CO (Leeward Islands/Antigua and Montserrat Original Correspondence, National Archives, London), DD/TD/15/6 and T/PH/swd (Tudway Family Antiguan papers and transcripts, Somerset Archive and Record Office, Taunton), COD (Codrington Papers Microfilms, British Library, St. Pancras, London), AL321 (Letters of Samuel Quincy, Senate House Library, London), PA and OL (Moravian Missionary Periodical Accounts and Original Letters, Moravian Church Library and Archive, Muswell Hill, London). Where available and appropriate, these codes will be followed by volume/series number, page number(s), item identifiers (i.e. author, addressee for correspondence or title for other documentation) and date.

${ }^{6}$ For a recent discussion of the nature and value of climate history research, see Mark Carey, Philip Garone, Adrian Howkins, Georgina Endfield, Lawrence Culver, Sherry Johnson, Sam White and James Fleming, 'Forum: climate change and environmental history', Environmental History, 19 (2014): p. 283.

${ }^{7}$ Noteworthy examples include Mike Davis, Late Victorian Holocausts: El Niño famines and the making of the Third World (London: Verso, 2001); Georgina Endfield, Climate and society in colonial Mexico: a study in vulnerability (Oxford: Blackwell Publishing, 2008); James Beattie, Emily O'Gorman and Matthew Henry, Climate, science, and colonialism: histories from Australia and New Zealand (New York: Palgrave Macmillan, 2014).

${ }^{8}$ Matthew Mulcahy, Hurricanes and society in the British Greater Caribbean, 1624-1783 (Baltimore: Johns Hopkins University Press, 2006). Stuart Schwartz, Sea of storms: a history of hurricanes in the Greater Caribbean from Columbus to Katrina (New Jersey: Princeton University Press, 2015).

${ }^{9}$ Sherry Johnson, Climate and catastrophe in Cuba and the Atlantic World in the Age of Revolution (Chapel Hill: University of North Carolina Press, 2011), p. 4; Sherry Johnson, 'Climate, community, and commerce among Florida, Cuba and the Atlantic world, 1784-1800', The Florida Historical Quarterly 80 (2002): 455-482; Sherry Johnson, 'The St. Augustine Hurricane of 1811: disaster and the question of political unrest on the Florida Frontier', The Florida Historical Quarterly 84 (2005): 28-56.
} 
There have been few climate histories focusing on the Lesser Antilles or the period of the American Independence War specifically. ${ }^{10}$ The present study addresses this scope for original investigation by applying an approach akin to that of Sherry Johnson to the case of Antigua during the American Independence War. Following a brief description of the environmental and socio-economic setting of the study, we examine in depth the anatomy of the crisis that affected the island between 1775 and 1783. Evidence is presented of the implications of drought for agricultural production, public health, socio-economic stability and governmental crisis management. This analysis is then supplemented with accounts of other periods of climatic stress (that is to say, other episodes when extreme weather events threatened colonial livelihoods) in the late eighteenth and early nineteenth centuries. By building upon this empirical foundation, we illustrate how drought -in particular, consecutive years of drought - played a critical role in defining the state of emergency that arose in Antigua during the war period. In as much, we conclude that climate acted with unique agency in the milieu of a precarious slavery- and monoculture-based colonial regime, stretched to breaking point by commercial and geopolitical forces.

\section{Context of study: environment, society and war}

Antigua lies at the centre of the Leeward Islands, the 300-km, crescent-shaped archipelago forming the northern half of the Lesser Antilles (Figure 1). The climate of this region is characterised by warm average temperatures of $23-25^{\circ} \mathrm{C}$ throughout the year and a pronounced annual pattern of precipitation and cyclonic activity. The wet season, which accounts for some two-thirds of rainfall, spans from May to November. It is marked by a relative precipitation minimum around June and a maximum in September-October. Tropical cyclones may be experienced throughout the wet season, though the average strength and numbers of these storms is significantly higher in autumn. ${ }^{11}$ With predominantly low-lying topography, Antigua generates little dependable 'relief rainfall'. Consequently, the island can experience considerable year-to-year variability in precipitation levels, as well as severe, multi-year drought. Today, as in the colonial past, human vulnerability to drought has been amplified by Antigua's lack of permanent major freshwater features, such as rivers and streams. $^{12}$

The long-term reconstruction of precipitation variations in Antigua spanning 1770 to 1890 has been the focus of recent research. Based on the systematic analysis of descriptions of climate and weather phenomena in contemporary documentary sources, semi-quantitative chronologies of relative variations in rainfall levels have been developed for the island at annual and seasonal resolutions. Results indicate that the years 1776-1780 represented one of the longest continuous episodes of below-average rainfall levels in the reconstruction. ${ }^{13}$ As

\footnotetext{
${ }^{10}$ For other studies with this remit, see: James Lewis, 'A multi hazard history of Antigua', Disasters 8 (1984): 190-197; Simon Smith, 'Storm hazard and slavery: the impact of the 1831 great Caribbean hurricane on St. Vincent', Environment and History 18 (2012): 97-124; Schwartz, Sea of storms, Ch. 3.

11 Douglas Gamble and Scott Curtis, 'Caribbean precipitation: review, model and prospect', Progress in Physical Geography 32 (2008): 265-276; National Hurricane Centre, 'Tropical cyclone climatology', available at: www.nhc.noaa.gov/climo [accessed 28 Oct. 2015].

${ }_{12}$ Caribbean Conservation Association, Environmental profile of Antigua and Barbuda, (St. John's: USAID, 1991), pp. 9-12.

${ }^{13}$ Alexander Berland, Sarah Metcalfe and Georgina Endfield, 'Documentary-derived chronologies of rainfall variability in Antigua, Lesser Antilles, 1770-1890' Climate of the Past 9 (2013): 1337; Alexander Berland, 'Extreme weather and social vulnerability in colonial Antigua, Lesser Antilles, 1770-1890' (Ph.D. diss. University of Nottingham, 2015), p. 65. These publications provide comprehensive details of the reconstruction methodology employed, a brief overview of which follows: (1) all archival materials noted in footnote 5 from 1769-1891 were read and passages regarding the state of the climate transcribed verbatim; (2) direct references to meteorological conditions and climate phenomena (excluding discussion of their wider environmental or social implications) were isolated for analysis and sorted chronologically by rain-year (Dec-Nov); (3) where
} 
shown in Table 1, which summarises the rainfall variations documented during this episode, the evidence indicates that drought affected much of Antigua for five years between October 1775 and October 1780, broken by widespread precipitation only in September 1776 and October $1777 .{ }^{14}$ Below-average rainfall levels were again widely recorded between February 1782 and May 1783, after abundant precipitation in October 1780 and mixed conditions during 1781.

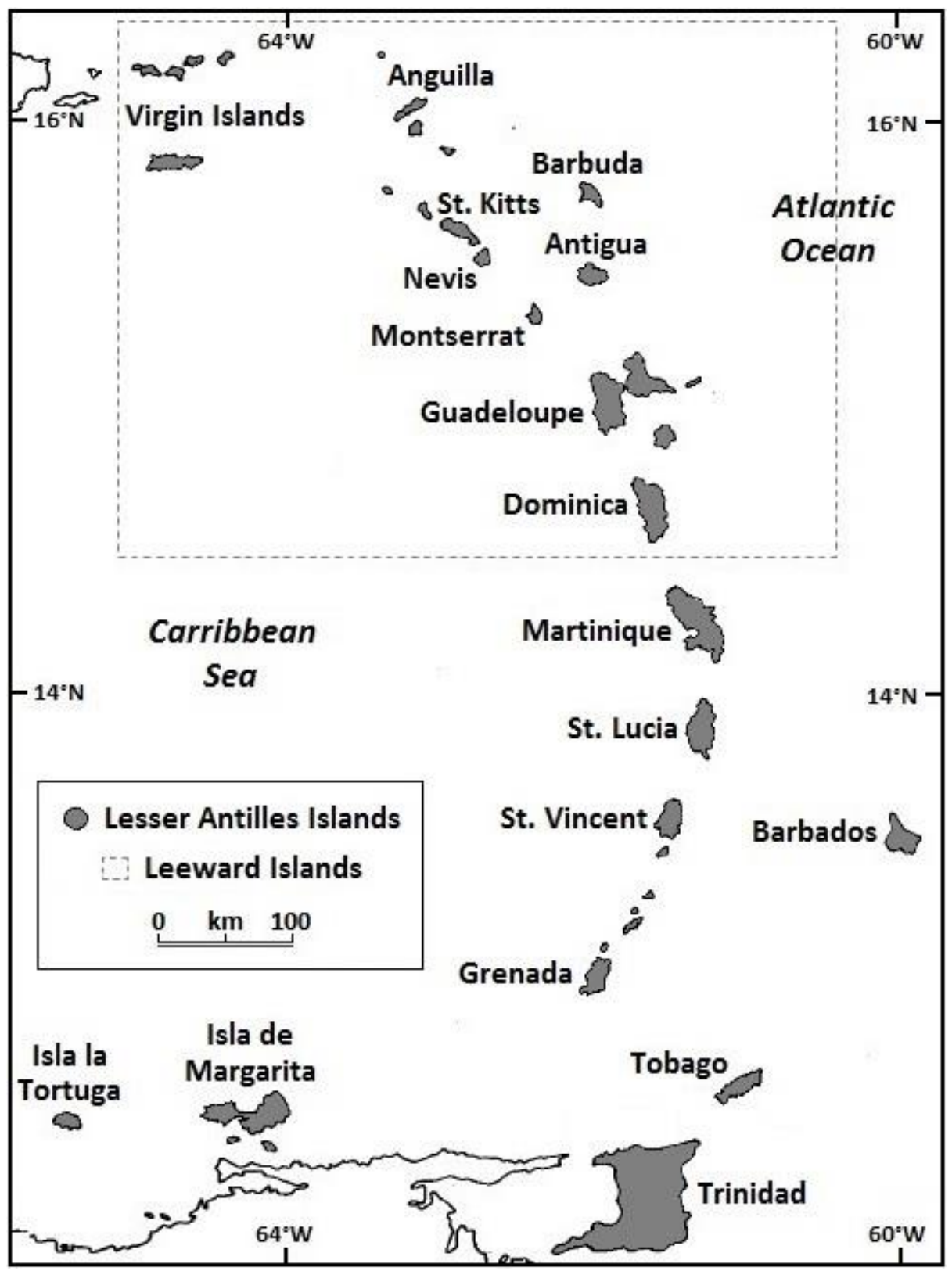

Figure 1. The Lesser Antilles and Leeward Islands.

sufficient evidence was available, each rain-year was assigned one of five classifications (very dry, dry, 'normal', wet or very wet) to reflect the predominant balance of rainfall levels throughout the year across the island; (4) the process was repeated for the individual dry and wet seasons of each rain-year using direct weather references pertaining to a specific locality in central-eastern Antigua; (5) classifications were plotted to create two near-continuous rainfall chronologies, one for the whole island resolved annually for the rain-years 1769-79 to 1889-90, the other for central-eastern Antigua resolved seasonally for 1769-70 to 1853-54.

${ }^{14} \mathrm{As}$ in the climate reconstructions published by Berland and colleagues, the present paper uses the term drought to refer to what is technically 'meteorological drought' - a deficit in precipitation relative to average levels for a given region over a given timespan. 
These weather events commenced at the height of the West Indian age of 'sugar and slavery'. ${ }^{15}$ The 1750 s through mid-1770s witnessed the most profitable years of the British Caribbean plantation economy, with sugar commanding a high retail value, a powerful navy protecting shipments to the metropolitan market and continuous imports of West African slaves ensuring a cheap and abundant workforce. At this time, over 220 of Antigua's $280 \mathrm{~km}^{2}$ land area was accounted for by some 300 sugar estates. Operating a continuous yearly cycle of monoculture and quasi-industrial production, these holdings generated the capital that underpinned the entire economy. As the largest sugar exporter in the Lesser Antilles and the seat of British governance in the Leeward Islands, Antigua was a key commercial and political hub. It was also an important military centre, home to a major naval dockyard at English Harbour and a permanent garrison of troops-including the aforementioned $60^{\text {th }}$ Regiment - which grew during the war years of the late 1700s. Nonetheless, the island's society was as polarised as elsewhere in the British Caribbean. A small white population, which stood at roughly 2,500 in 1774, monopolised political affairs, trade and the profits of the sugar industry. Meanwhile, a 37,000-strong African-descended underclass-kept in line by a constant military presence and institutionalised violent discipline-faced an existence of enforced servitude. Though a sizable minority of non-whites received preferential treatment for domestic service or specialised craftwork, most toiled as field labourers under conditions that were gruelling in the extreme. Excessive mortality rates associated with inadequate food rations and high disease incidence were offset only by continuous slave imports, which reached an estimated average of 2,000 per year in the mid-1700s. ${ }^{16}$

Table 1. Summary of evidence of rainfall levels in Antigua, 1775-1783, and examples of contemporary descriptors of these conditions, based on archival research by Berland and coauthors. $^{17}$

\begin{tabular}{|l|l|l|}
\hline Year & Conditions & Example descriptors \\
\hline \multirow{3}{*}{1775} & $\begin{array}{l}\text { No conclusive evidence of weather } \\
\text { conditions Jan.-Sept. }\end{array}$ & n/a \\
\cline { 2 - 3 } & Deficient rainfall in Oct.-Dec. & 'little rain', 'very dry', 'severe drought' \\
\hline 1776 & Deficient rainfall Jan.-Jul. & 'dry weather', 'very dry', 'severe drought' \\
\cline { 2 - 3 } & Short showery spell in late May & 'tolerable showers' \\
\cline { 2 - 3 } & $\begin{array}{l}\text { Seasonable rains and a weak tropical } \\
\text { cyclone in Sept. }\end{array}$ & 'fine rains', 'three weeks of good rain' \\
\cline { 2 - 3 } & Rainfall deficiency Oct.-Nov. & 'nothing of rain' \\
\hline 1777 & $\begin{array}{l}\text { Severe rainfall deficiency in all months } \\
\text { except Oct. }\end{array}$ & $\begin{array}{l}\text { 'a scene of dry weather', 'excessive dry } \\
\text { weather', 'great drought' }\end{array}$ \\
\cline { 2 - 3 } & Seasonable rains in Oct. & 'good rain', 'a season of rain' \\
\hline 1778 & Severe rainfall deficiency Jan.-Dec. & $\begin{array}{l}\text { 'very dry weather', 'extremely dry', 'long } \\
\text { severe spell of dry weather' }\end{array}$ \\
\hline
\end{tabular}

${ }^{15}$ A thematic period explored extensively by Richard Sheridan, Sugar and slavery: an economic history of the British West Indies, 1623-1775 (Baltimore: Hopkins University Press, 1974).

${ }^{16}$ Richard Sheridan, 'The rise of a colonial gentry: a case study of Antigua, 1730-1775' The Economic History Review 13 (1961): 343; Sheridan, Sugar and slavery, 194-196; For other comprehensive accounts of slave society, see Barry Gaspar, Bondmen and rebels: a study of master-slave relations in Antigua (London: John Hopkins University Press, 1985), esp. chaps. 4-6; Andrew O'Shaughnessy, 'Redcoats and slaves in the British Caribbean', in R.L. Paquette and S.L. Engerman (eds.) The Lesser Antilles in the age of European Expansion, pp. 105-127 (Gainsville: University Press of Florida, 1996); Brian Dyde, A History of Antigua: the Unsuspected Isle (London and Oxford: Macmillan Education, 2000), pp. 85-92; Kenneth Morgan, Slavery and the British Empire: from Africa to America (Oxford: Oxford University Press, 2007), chaps. 1-2, 4-5.

17 Berland, Metcalfe and Endfield, 'Documentary-derived chronologies of rainfall': 1332-1334; Berland, 'Extreme weather and social vulnerability', chaps. 4-5. 


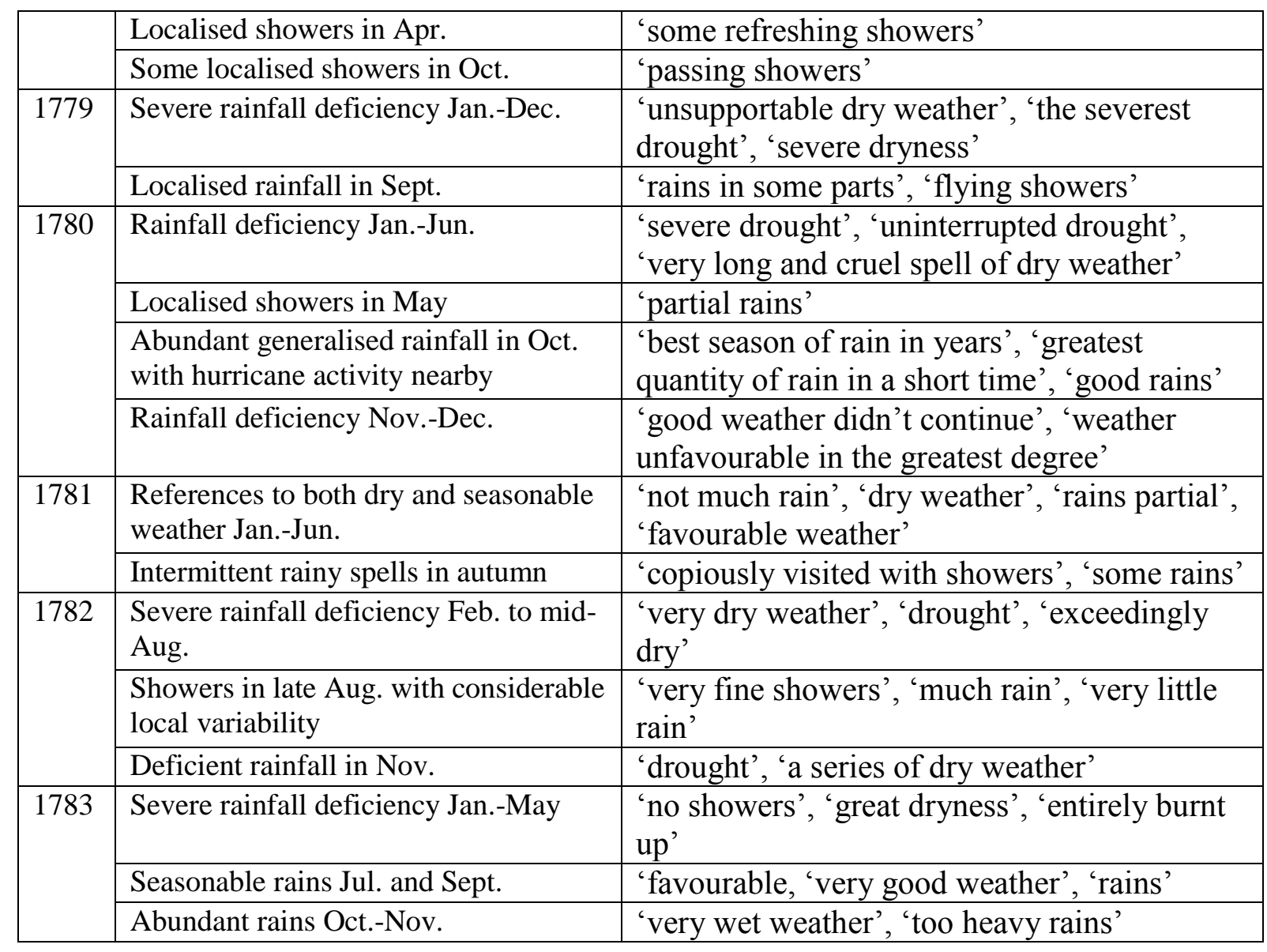

Despite the riches being generated by enslaved plantation labour, all was not well in Britain's New World Empire during the early 1770s. Frustration with Crown rule in the thirteen longstanding North American colonies-which stretched from Massachusetts to Georgia on the east coast (Figure 2) - had reached fever pitch by 1774 . This culminated in the resolution of the first 'Continental Congress' to ban all imports from Britain, Ireland and the West Indies as of December that year, a policy known as the Continental Association. Britain responded by launching an extensive military campaign against the rebelling provinces the following April, bringing an end to outbound trade, as well as the already suspended inbound commerce, between the Thirteen Colonies and the remainder of the Empire. $^{18}$ The commercial embargo, which was upheld until American Independence in September 1783, spelled calamity for the British Caribbean. It eliminated the principal supply of hardware and raw materials fundamental to plantation operations (timber, tools, rope and machinery components), as well as the non-local foodstuffs that sustained the region's human population (maize, flour and salted meats). Meanwhile, an increased military and naval presence to secure the island colonies increased pressure on supplies. Nowhere was the blockade felt more keenly than in the Leeward Islands, where sugarcane monoculture was most intense and, owing to the consequent neglect of subsistence agriculture, dependence upon imports was greatest. ${ }^{19}$ The situation worsened in the late $1770 \mathrm{~s}$, when hostilities broke out with other colonial powers. France entered the conflict in alliance with the Thirteen Colonies in March 1778, followed by Spain in 1779 and Holland in 1780. In the battleground

\footnotetext{
${ }^{18}$ Eric Williams, From Columbus to Castro: the history of the Caribbean 1492-1969 (London: André Deutsch Limited, 1970), pp. 217-226; Richard Sheridan, 'The crisis of slave subsistence in the British West Indies during and after the American Revolution', The William and Mary Quarterly 33 (1976): pp. 615-618.

${ }^{19}$ Sheridan, 'The crisis of slave subsistence': 622-624.
} 
that the Caribbean became, the eastern islands once again bore the greatest excesses, witnessing a maelstrom of territorial gains, losses and re-acquisitions (though Antigua was the target of no major attack or invasion). ${ }^{20}$

In this disastrous context, procuring provisions from new sources became vital for the British West Indies. From within the empire, supplies were sent from the British Isles and loyal North American colonies. From without, imports were periodically permitted from nonhostile foreign dominions, which often served simply to redirect cargoes from enemy territory. At the same time, many British planters reduced reliance on imports by expanding the acreage devoted to subsistence crops, such as yams, cassava and potatoes, which slaves normally cultivated on small tracts of marginal land to supplement their imported rations. While this was a practise most widely adopted in the extensive fallow lands of Jamaica, some estate owners in the Lesser Antilles also replanted caneland with provisions. ${ }^{21}$ Despite such adaptations, the academic consensus is that the conflict of 1775-1783 precipitated an unprecedented crisis in the region. Famine and sickness ravaged slave populations, whichoverworked and underfed at the best of times - were acutely susceptible to food shortages. With a lack of crucial hardware coinciding with problems of labour supply, plantation output fell just as running costs rose. Prices of many staples more than doubled in the Leewards, while sugar exports from the British Caribbean plummeted by 40 per cent between 1774 and 1778. The plantation economy also endured numerous secondary stresses, including increased taxes and shipping costs. ${ }^{22}$ In these ways, the social and political circumstances of the war period rendered Caribbean societies peculiarly vulnerable to further stresses, such as storms and droughts. ${ }^{23}$

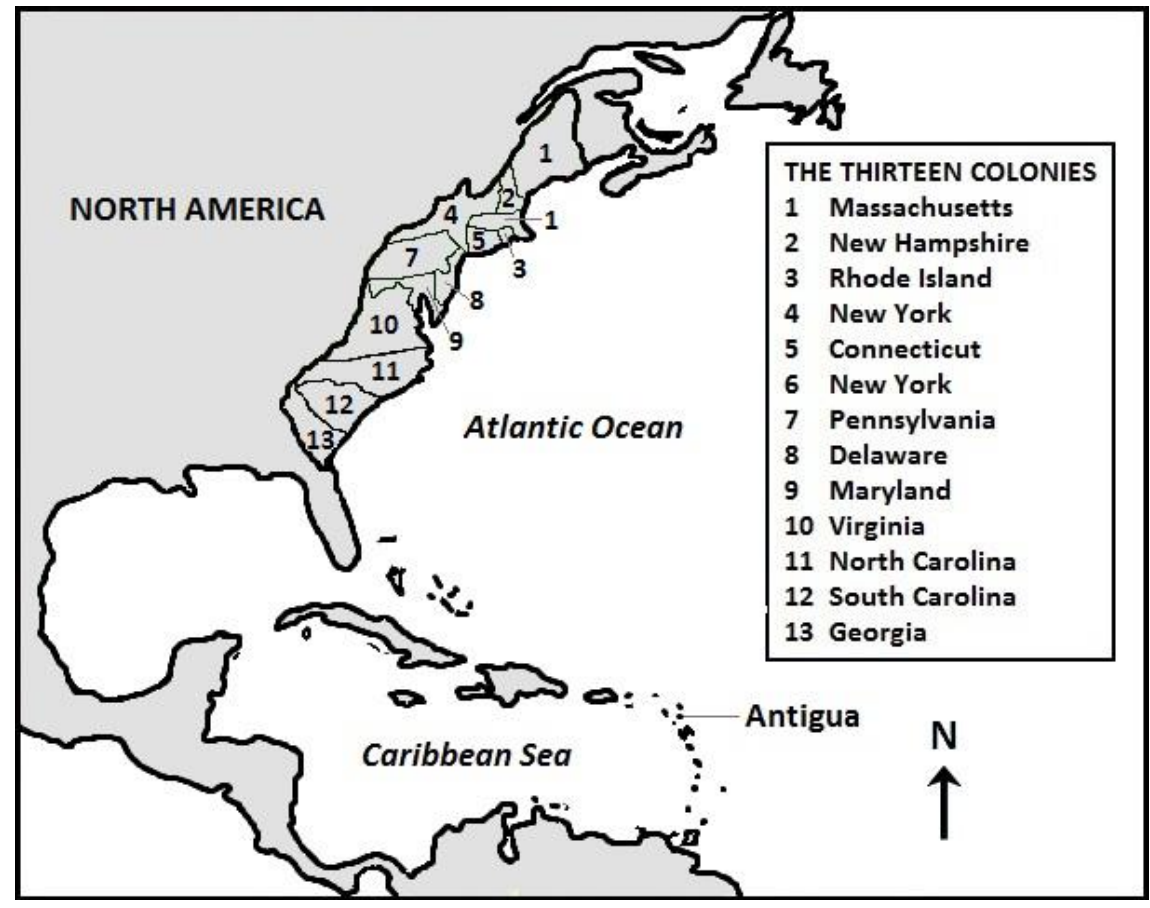

Figure 2. Britain's original thirteen colonies in North America.

\footnotetext{
${ }^{20}$ Lowell Ragatz, The fall of the Planter Class in the British Caribbean, 1763-1833 (New York: Octagon Books, 1963), p. 155; David Watts, The West Indies: Patterns of development, culture, and environmental change since 1492 (Cambridge: Cambridge University Press, 1987), pp. 252-253.

${ }^{21}$ Ragatz, The fall of the Planter Class, pp. 147-149; Sheridan, 'The crisis of slave subsistence': 618-619; John Ward, British West Indian Slavery, 1750-1834 (Oxford: Oxford University Press, 1988), pp. 20-24, 40-41.

${ }^{22}$ Ragatz, The fall of the Planter Class, pp. 142-172; Williams, From Columbus to Castro, pp.142-172; Sheridan, 'The crisis of slave subsistence'; Ward, British West Indian Slavery, pp. 40-41.

${ }^{23}$ Schwartz, Sea of storms, pp. 92-93.
} 


\section{Scarcity, morbidity and mortality in embattled Antigua}

3.1. 'Ye horrors of a Famine every day stare us more \& more in ye face'

Immediately before the turbulent war period, the British Leeward Islands had enjoyed consecutive years of commercial success. Writing in January 1775, the governor of the region, Sir Ralph Payne, enthused:

The Trade of every Island... is uncommonly flourishing; Provisions of all Kinds from the Continent of America are cheaper and more plentiful than they have been in the Memory of Man; and the Crops for the present Year, promise to be much superior even to those of the last, in Quality as well as in Quantity. ${ }^{24}$

In Antigua, consistently above-average rainfall levels were experienced between August 1772 and October 1774, which contributed to a bumper sugar crop in 1774, succeeded by the largest of the eighteenth century one year later (Figure 3a). ${ }^{25}$ For their part, in 1775 , the plantations of one of the largest landholders in the island, Sir William Codrington, generated the second highest yield then on record (Figure $3 \mathrm{~b}$ ). Committed to protecting their industry, planters reacted quickly to the news of deteriorating Anglo-American relations. While commercial channels with the continent remained open, purchases of provisions were increased to build up reserves. Simultaneously, reported one estate attorney, agriculturalists began to plant 'every sort of Provisions'. ${ }^{26}$ However, the attorney also offered an ominous word of caution: should the supply of American produce halt, he noted, 'we shall be reduced to great distress, especially if we have any long spells of dry weather, as we sometimes do'. ${ }^{27}$

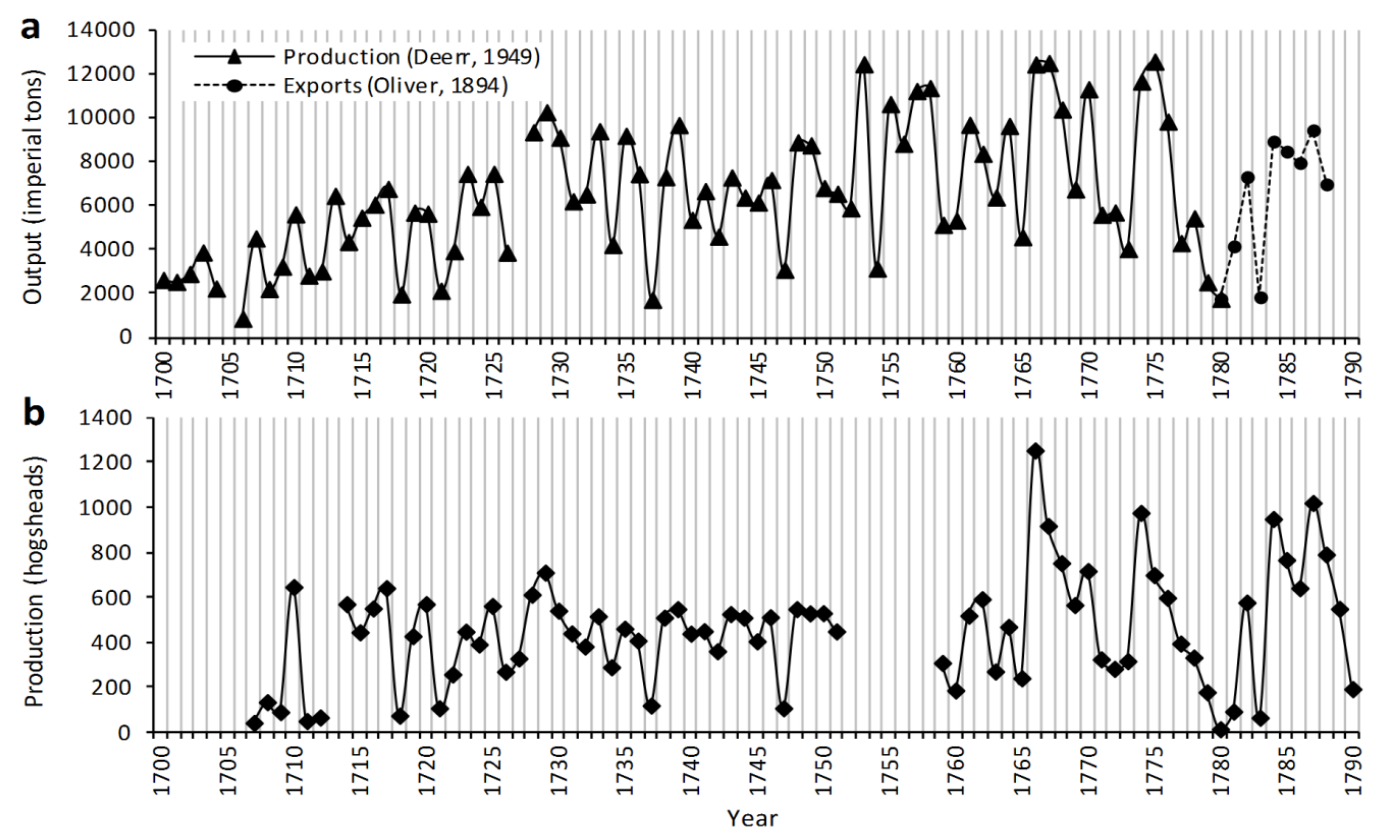

Figure 3. (a) Annual Antiguan sugar production and exports and (b) combined annual sugar production of the Codrington family's principal Antiguan estates, 1700-1790. ${ }^{28}$

\footnotetext{
${ }^{24}$ CO152/55, Gov. Payne to Earl of Dartmouth, 12 Jan 1775.

25 Berland, Metcalfe and Endfield, 'Documentary-derived chronologies of rainfall': 1338-1339; Berland, 'Extreme weather and social vulnerability', p. 70.

${ }^{26} \mathrm{DD} / \mathrm{TD} / 15 / 6$, S. Blizard to C. Tudway, 21 Jul. 1775.

${ }^{27}$ Ibid.

${ }^{28}$ Data from Noël Deer, The history of sugar, Volume I (London: Chapman and Hall, 1949), p. 195; Vere Oliver, The history of the island of Antigua, one of the Leeward Caribbees in the West Indies, from the first
} 
Unhappily for Antigua, it was not long before these preconditions were met; trade embargos between the thirteen colonies of North America commenced late in 1775, as did a protracted phase of precipitation deficiency (Section 2). On 29 December, plantation manager Francis Farley wrote to Sir Clement Tudway, another important absentee plantation owner, that Antigua's provision reserves were running low. 'People... would gladly appropriate [a] good part of their caneland to raising provisions,' Farley asserted, 'had we rain to plant with'. ${ }^{29}$ Complaints gradually became more strident as the concomitant pressures of dry weather and dwindling supplies mounted. ${ }^{30}$ Come April 1776, Mainswete Walrond, another of Sir Tudway's estate managers, simply lamented: 'ye horrors of a Famine every day stare us more \& more in ye face'. ${ }^{31}$ Three months later, he added that island-wide water shortages had claimed the lives of 'a great number of cattle'. 32

Fortunately for Walrond and his fellow Antiguans, the next twelve months brought brief respite; subsistence crops were sewn with showers in May and September, ${ }^{33}$ a temporary ban on exports slowed the depletion of stockpiles and the capture of American craft by British privateers supplied 'Plenty of Provisions. ${ }^{34}$ However, when maritime trade took its seasonal dip in the hurricane season of 1777 , acute scarcities returned, drought having prevailed since the previous October. ${ }^{35}$ As early as July 1777, Farley noted that imported corn and beans had run out across the island, while local food and water sources were exhausted. ${ }^{36}$ Famine set in that autumn. In his next letter, dated 27 October, the estate manager exclaimed: 'I believe from 1000 to 1500 Negroes will be lost in consequence of this scarcity; many are already dead'. ${ }^{37}$ Hunger continued through the opening months of 1778, proving Falrey's fears alarmingly accurate. In a letter to the Colonial Office in mid-March, the governor of the Leewards grieved: 'from the best informations [sic] I have been able to collect, The Island of Antigua has lost above a thousand Negroes', 38

\section{2. 'Its face the deserts of Arabia'}

The crisis climaxed over the next two years. France's entrance into the war left Antigua reliant upon perilous trade with the Empire and a few neutral states, as well as irregular captures at sea. ${ }^{39}$ Accounts speak comprehensively of these difficulties and the confounding affects of dry weather. Francis Farley, for example, penned the following in September 1778:

It has been long extremely dry \& more so at present than I ever before knew it, both Water \& provisions are scarcer than they ever were in the Memory of Man and this without a prospect of relief as to provisions for a considerable time, [as] it is unlikely

settlement in 1635 to the present time, Volume I (London: Mitchell and Hughes, 1894), p. cxxxviii, values converted from hogsheads to imperial tons; COD/A62, 'Sugar made on the Codrington Plantations from 1707', undated.

${ }^{29}$ DD/TD/15/6, F. Farley to C. Tudway, 29 Dec. 1775.

${ }^{30}$ E.g. DD/TD/15/6, M. Walrond to C. Tudway, 20 Jan. 1776; 28 Mar. 1776; 18 Mar. 1776.

${ }^{31} \mathrm{DD} / \mathrm{TD} / 15 / 6$, M. Walrond to C. Tudway, 20 Apr. 1776.

${ }^{32} \mathrm{DD} / \mathrm{TD} / 15 / 6, \mathrm{M}$. Walrond to C. Tudway, 20 Jul. 1776.

${ }^{33}$ Ibid.; DD/TD/15/6, F. Farley to C. Tudway, 13 Sept. 1776, 25 Sept. 1776, R. Martin to C. Tudway, 25 Sept. 1776.

${ }^{34}$ CO152/55, C. Greathead to Lord Germain, 5 Jun. 1776; CO152/56, Gov. Burt to Lord Germain, 4 May 1777.

35 Throughout the colonial West Indies, few trade vessels sailed between August and October of each year, when the risk of hurricane occurrence is greatest.

${ }^{36}$ DD/TD/15/6, F. Farley to C. Tudway, 27 Jul. 1777.

${ }^{37} \mathrm{DD} / \mathrm{TD} / 15 / 6$, F. Farley to C. Tudway, 27 Oct. 1777.

${ }^{38}$ CO152/57, Gov. Burt to Lord Germain, 17 Mar. 1778.

${ }^{39}$ CO152/58, Gov. Burt to Lord Germain, 15 Aug. 1778; CO152/59, Gov. Burt to Lord Germain, 2 Nov. 1778. 
that the fleet from London will be here before Christmas and should we be blessed with plentiful rains immediately we can't raise any Provisions in less than four months. ${ }^{40}$

Even the arrival of emergency supplies the following March could not avert disaster. At the start of May 1779, Governor Burt wrote of the Antiguan populace:

Their present Crops are Distroyed [sic] by a long[,] very long severe Drought; nor have they now any prospect of a succeeding Crop: they have not had a thorough Season of Rain since October was a Twelve Month: Their Cysterns [sic] are and hav[e] been some time Emptied; their large Ponds are in the same State; they are compelled to carry Water for their Families' use many Miles, for which they pay eighteen Pence a Gallon. Heavan [sic] has denied them not only Seasons but even refreshing Showers from whence they might raise Pulse and Vegetables or some Provisions for their Negroes... My letters from that Island paint nothing but ruin and its face the deserts of Arabia. ${ }^{41}$

That September, Burt could only add that 'many hundreds of Negroes' had starved to death. ${ }^{42}$ Contemporaries also reported vast (though un-numerated) mortality among the island's cattle. $^{43}$

All the while, another ecological force amplified death and despair. In June 1777, doubts arose as to how long Sir Tudway's slaves would remain healthy while drought obliged them 'to drink bad water'. ${ }^{44}$ Eleven months on, amid further commentary of the unwholesome quality of Antigua's depleted water supplies, the first fatality of a widespread dysentery outbreak was registered on the absentee's estates. ${ }^{45}$ Another year later, 'all the Negroes in the Island' were said to be 'very sickly, chiefly with ye flux' ${ }^{46}$ Records reviewed by colonial historian John Ward indicate that, overall, one tenth of Tudway's slaves perished between summer 1779 and autumn 1780, primarily due to dysentery. ${ }^{47}$ Similarly, in 1778-1779, the death toll on two of Sir Codrington's plantations, Betty's Hope and The Garden, was calculated at 15 per cent. ${ }^{48}$ Yet, it seems that Codrington's and Tudway's workforce were spared the full excesses of the epidemic. When interviewed by parliament years later, Antiguan physician Samuel Athill estimated from his examinations that dysentery had killed between a fourth and a fifth of Antiguan slaves (i.e. some 7,500-9,000) in the years 1778$1780 .^{49}$ And it was not only the enslaved who suffered; Francis Farley, for instance, was named in a list of five whites who lost their lives in the epidemic. ${ }^{50}$

Antigua's situation improved temporarily from the summer of 1780, British food aid arriving, the dysentery epidemic abating and spells of wet weather in October and throughout

\footnotetext{
${ }^{40}$ DD/TD/15/6, F. Farley to C. Tudway, 27 Sept. 1778.

${ }^{41}$ CO152/59, Gov. Burt to Lord Germain, 3 May 1779.

${ }^{42}$ CO 152/34, Gov. Burt to Board of trade and Plantations, 26 Sept. 1779.

${ }^{43}$ DD/TD/15/6, M. Walrond to C. Tudway, 19 Aug. 1779, 29 Mar. 1780.

${ }^{44}$ DD/TD/15/6, R. Martin to C. Tudway, 1 Jun. 1777.

${ }^{45}$ DD/TD/15/6, M. Walrond to C. Tudway, 19 Jul. 1778.

${ }^{46}$ DD/TD/15/6, M. Walrond to C. Tudway, 19 Aug. 1779.

${ }^{47}$ Ward, British West Indian Slavery, p. 66.

${ }^{48}$ COD/C10, R. Clarke to W. Codringon, Jan. 1780 [precise date unspecified].

49 'Report on the Slave Trade,' Parliamentary Papers, XXVI (I789) Report 646a, Pt. 3, Antigua, A. No. i5, p. 31; In an earlier letter to William Codrington (COD/C16, S. Athill to W. Codrington, 1 Mar 1780), Dr. Athill specifically asserted that the proprietor's loss had been 'less in proportion than any other Estate in the Island'. The discrepancy in the quoted mortality figures likely owes to the fact that few other Antiguan estates were as well financed as those of Codrington and Tudway, who could invest more in slave healthcare.

${ }^{50} \mathrm{DD} / \mathrm{TD} / 15 / 6$, M. Walrond to C. Tudway, 29 Sept. 1779. Unfortunately, this document offers no further details about the background of these whites, or the circumstances of their death.
} 
1781 gradually restoring water supplies and agriculture. ${ }^{51}$ The island was also singularly fortunate in escaping virtually unscathed from the devastating effects of a hurricane which tore through the Lesser Antilles in early-mid October $1780 .{ }^{52}$ However, subsistence problems did not disappear entirely; food prices remained high and scarcities again occurred in the 1781 storm season. ${ }^{53}$ And, when drought returned at the start of 1782 , so too did water shortages, livestock mortality and a floundering slave subsistence sector. ${ }^{54}$ Recovery began only in the summer of 1783, with the onset of nine months of wet weather and the war soon reaching an end. ${ }^{55}$ 'We now have plenty of good water, \& a tolerable quantity of grass, \& I hope to get the cattle \& mules in good order for taking off the crop' acclaimed Mainswete Walrond towards the end of September. ${ }^{56}$ By this time, 'great supplies of provisions \& lumber' had already been imported, trade with the now-independent thirteen colonies having recommenced early that month. ${ }^{57}$

\section{4. 'To destroy the hope of the planter': the political economy imperilled}

For most planters and government officials, who rarely lacked everyday necessaries despite high prices, dearth and mortality were of concern foremost for their impacts on the sugar industry. Harvest and export data (Figure 3) offer a useful framework for assessing contemporary ebbs and flows in this sector. Bearing in mind that annual totals reflect conditions throughout the preceding 12-16 months of cane growth and processing, ${ }^{58}$ notable coherence is evident between sugar output and the pattern of fluctuating material circumstances presented above; exports and production fall after 1775 to reach their nadir in 1780, rise moderately from 1781 to 1782 and then collapsed once more in 1783 .

Drought was perhaps the most direct driver of decline. The archives contain countless references to its consequences for sugarcane cultivation, over timescales ranging from weeks to years. ${ }^{59}$ The earliest examples date from spring 1776, when Mainswete Walrond observed:

ye weather continues very dry \& ye Canes are burning fast thro all ye Country which will soon alter ye quality of ye sugar much $\&$ lessen ye quantity. ${ }^{60}$

When, in 1780, sugar yields plummeted, the predicament faced by Antiguan planters was summarised by Sir Codrington's chief Antiguan attorney as follows:

\footnotetext{
${ }^{51}$ COD/C10, R. Clarke to W. Codrington, 19 May 1780, 15 Oct. 1780, 26 Apr., 29 Jun. 1781; COD/C11, J. Lindsay to W. Codrington, 18 Oct. 1780; DD/TD/15/6, M. Walrond to C. Tudway, 26 Sept. 1780, 7 Oct. 1780, 10 Nov. 1780, 28 Nov. 1781.

${ }^{52}$ CO152/60, Gov. Burt to Lord Germain, 1 Nov. 1780. For detailed accounts of the effects of this storm, which came to be known as the 'Great Hurricane', see Schwartz, Sea of storms, pp. 193-196; Mulcahy, Hurricanes and society in the British Greater Caribbean, pp. 76-82; Edward Rappaport and Jose Fernández-Partagás, 'History of the deadliest Atlantic tropical cyclones since the discovery of the New World', in H. Diaz and R. Pulwarty, (eds.) Hurricanes: climate and socioeconomic impacts, pp. 93-108 (Berlin: Springer, 1997).

${ }^{53}$ CO152/61, T. Jarvis and R. Burton to A. Johnson, 6 Apr. 1781, Gov. Shirley to Lord Germain, 30 Aug. 1781; DD/TD/15/6, J. Grey to C. Tudway, 29 Nov. 1781.

${ }^{54}$ CO7/1, R. Oliver to anonymous, 4 Jun. 1782; CO152/62, Gov. Shirley to Lord Townsend, 8 Nov. 1782; DD/TD/15/6, M. Walrond to C. Tudway, 12, 31 Aug. 1782.

${ }_{55}^{50} \mathrm{DD} / \mathrm{TD} / 15 / 6$, M. Walrond to C. Tudway, 17 Mar. 1784.

${ }^{56} \mathrm{DD} / \mathrm{TD} / 15 / 6, \mathrm{M}$. Walrond to C. Tudway, 26 Sept. 1783.

${ }^{57} \mathrm{DD} / \mathrm{TD} / 15 / 6, \mathrm{~S}$. Elliot to C. Tudway, 27 Sept. 1783.

${ }^{58}$ For a comprehensive account of the process of sugar making, see Sheridan, Sugar and Slavery, pp.107-118.

${ }^{59}$ To cite but a few: DD/TD/15/6, Letters to C. Tudway from F. Farley, 11 Jun. 1777; J. Grey, 27 Sept. 1778; S. Elliot, 29 Apr. 1779; J. Grey, 11 Jun. 1779.

${ }^{60}$ DD/TD/15/6, M. Walrond to C. Tudway, 18 Apr. 1776.
} 
we are now as dry as 'tis possible [to be] and the Canes are perishing daily, whilst the Season is but already too far advanced to replant with hopes of success or to form any great dependence [sic] upon Canes that have been so materially injured in their infant State. ${ }^{61}$

Conversely, a resurgence in production in 1781 (Figure 3) was attributed to favourable weather that spring. ${ }^{62}$ Rainfall deficiency was, nevertheless, to return for the subsequent two years, 'totally to destroy the hope of the Planter'. ${ }^{63}$ All the while, the manufacture of sugar was undermined by shortages of vital equipment and the replanting of caneland with subsistence crops. ${ }^{64}$ However, once famine and disease ensued, an enfeebled workforce became planters' principal challenge. So many slaves had died by June 1780, claimed one of Sir Codrington's correspondents, that even if the year's crop had been large, 'there would have been almost unsumountable [sic] difficulties in taking it off' ${ }^{65}$

With the sugar industry as the motor of the colonial economy, it wasn't long before recurrent harvest failure precipitated financial ruin. This emerged first at the plantation level. As one anonymous visitor to the island explained in November 1781:

Where there is so great a failure of yearly revenue, the expense of maintaining such a number of negroes as is necessary for cultivating these Estates, must be prodigious. The plantation unable to yield its accustomed quantity of vegetables is insufficient for the support of the negroes settled on it, and the owner must supply the deficiency by purchasing, which he is unhappily necessitated to do, at a time when he can least afford it. $^{66}$

Pecuniary difficulties were only aggravated by mortality among livestock and the enslaved. ${ }^{67}$ For instance, loss of the labour of eighty Codrington slaves who perished in 1777 and 1778 was estimated to have cost the proprietor $£ 4,000 .{ }^{68}$ When subsequent hostilities between England and France rendered commercial conditions completely untenable, securing credit from merchants became all but impossible. ${ }^{69}$ Thus, many plantations became trapped in a cycle of decline; as climatic and geopolitical threats to plantation operations diminished investor confidence, the overseas investment needed to sustain production evaporated, reducing operational efficiency and output further. The cycle was broken only when intractable debt drove proprietors out of the sugar industry altogether. So widespread was bankruptcy by the end of 1779, that Antiguan politicians renewed seldom-enforced legislation for 'Preventing the Escape of Debtors'. 70

Linked as they were through taxes and shipping duties, private insolvency quickly translated into public insolvency. As mentioned in Section 1, the colonial treasury was already depleted by autumn 1777. Military expenditure only mounted thereafter. Government

\footnotetext{
${ }^{61}$ COD/C8, L. Lovell to W. Codrington, 10 Jun. 1780.

${ }^{62} \mathrm{COD} / \mathrm{C} 10, \mathrm{R}$. Clarke to W. Codrington, 29 Jun. 1781.

${ }^{63}$ CO152/63, Gov. Shirley to Lord Townsend, 15 Apr. 1783.

${ }^{64}$ DD/TD/15/6, F. Farley to C. Tudway, 19 Jun. 1776, M. Walrond to C. Tudway, 26 Jun. 1782; CO152/58, Gov. Burt to Lord Germain, 15 Aug. 1778.

${ }^{65} \mathrm{COD} / \mathrm{C} 10, \mathrm{R}$. Clarke to W. Codrington, 8 Jun. 1780. A similar comment was made after an island-wide measles epidemic in 1783; DD/TD/15/6, M. Walrond to C. Tudway, 15 Apr. 1783.

${ }^{66}$ Oliver, The history of the island of Antigua, p. cxxv.

${ }^{67}$ E.g. DD/TD/15/6, F. Farley to C. Tudway, 29 Dec. 1775, M. Walrond to C. Tudway, 10 Jun. 1778, 11 Feb. 1779, 29 Mar. 1780; COD/C10, R. Clarke to W. Codrington, 12 Jun. 1779, 18 Jul. 1781.

${ }^{68} \mathrm{COD} / \mathrm{C} 12, \mathrm{R}$. Oliver to W. Codrington, 14 Jul. 1783.

${ }^{69}$ CO152/59, Gov. Burt to Lord Germain, 3 May 1779.

${ }^{70}$ CO152/34, Report of R. Jackson, 28 Dec. 1779.
} 
accounts indicate that some $£ 80,000$ (which, accounting for inflation, would today amount to roughly $£ 5$ million) was invested in defence between 1777 and 1783 -approximately 80 per cent of the total spent from 1776 to $1790 .^{71}$ After teetering at the brink of complete insolvency for two years, the colony eventually received British financial aid in 1780 (see Section 5). Nevertheless, by 1783, the legislature had again 'run amazingly into debt' ${ }^{72}$

It is noteworthy that, while discussing connections between the trade embargo, warfare and economic downturn, Antiguan officials also repeatedly underscored the significance of deficient rainfall. ${ }^{73}$ Particularly emphatic were the words of the Assembly in a three-page testimonial on the matter:

For more than seven years... has this unhappy Colony been visited with a Drought, the severity of which cannot be more justly described than by a detail of the disappointments \& Misery it has produced. Our Crops have been destroyed-our Labours and Industry frustrated - Our debts accumulated by a deprivation of the only means to reduce them. Families falling from Ease \& Affluence into Penury and Want, have been obliged to abandon the Estates of their Ancestors. Our Lands... [have] become sterile, and debarred thereby of our Usual resources, our Expenses in the Cultivation of our Plantations have continually increased-Such has been and such is still the Situation. ${ }^{74}$

Though revealing much about the structural dimensions of the crisis, it must be recognised that the colonial archives offer a notably partial, elite-oriented perspective on human experience of climatic and agro-economic deterioration. The brutal realities lived by Antiguans of colour are largely only reflected in economic terms - as the loss of productive labour or the escalation of feeding and medical costs. ${ }^{75}$ Yet, even these dehumanising accounts offer some insights that problematise conventional portrayals of the enslaved as units of diminishing stock, passive to the onslaughts of crisis. In July 1780, for example, Governor Burt reported that planters 'had experienced great injury' as a result of the theft and illicit sale of plantation produce by blacks - a response to climate-related food shortages known to be common in nineteenth century Antigua. ${ }^{76}$ The white elite also apprehended more dangerous slave action. As early as December 1775, Mr. Farley warned:

Famine (the worst of all Evils) approaches fast, which may, \& probably will bring on a rebellion of our slaves, \& as there are about 35,000 of them in this Island, [but] not above 4,000 whites, we shall stand a bad chance. ${ }^{77}$

\footnotetext{
${ }^{71}$ CO152/67, Legislative minutes, 29 Jun. 1789; CO7/1, Report of W. Hutchinson, 21 Jan. 1791 (figures converted from 'colonial currency' to sterling). Notwithstanding military spending during the war period, there is evidence that Antigua's defensive capabilities may have been compromised by drought and commercial stagnation, as suggested by the case of the royal 60th Regiment recounted at the start of this paper. For other anecdotal illustrations of this point, see CO152/60, Gov. Burt to Lord Germain, 4 May 1780; CO152/62, Gov. Shirley to Lord Townsend, 8 Nov. 1782; DD/TD/15/6, F. Farley to C. Tudway, 27 sept. 1778

${ }^{72}$ CO152/63, Gov. Shirley to Lord North, 27 Jul. 1783.

${ }^{73}$ E.g. CO152/59, Gov. Burt to Lord Germain, 3 May 1779; CO7/1, R. Oliver to anonymous, 4 Jun. 1782; CO152/62, Gov. Shirley to Lord Townsend, 8 Nov. 1782; CO152/67, Legislative minutes, 29 Jun. 1789.

${ }_{75}^{74}$ CO152/63, Legislative petition, 28 May 1783.

75 For a discussion of 'silences' in the colonial sources, see James Duncan, 'Complicity and resistance in the colonial archive: some issues of method and theory in historical geography' Historical Geography 27 (1999): $119-128$.

${ }^{76}$ CO152/34, Gov. Burt to Board of Trade and Plantations, 28 Jul 1780; COD/C28, J. Osborn to C.B. Codrington, 27 Oct 1813; Berland, 'Extreme weather and social vulnerability', pp. 162-163, 189-191.

${ }^{77}$ DD/TD/15/6, F. Farley to C. Tudway, 29 Dec. 1775.
} 
In subsequent years, the same fear was reiterated by Farley as well as Mainswete Walrond. ${ }^{78}$ For his part, Governor Burt was convinced that his sanctioning of foreign provision imports in 1778 (see Section 5) had 'prevented Insurrections among the slaves'. ${ }^{79}$

In the end, Antigua was lucky, for the African-descended masses staged no rebellion attempt during the war. Violent slave dissent on a smaller scale did, however, take place at least twice. Late in March 1780, head-manager Richard Clarke informed Sir Codrington that three of the proprietor's slaves had been condemned to execution for attempting to poison several of his white plantation staff. Clarke also revealed that one of the intended victims, the manager of 'Tuites' estate, had been the target of a similar attempt 18 months earlier. ${ }^{80}$ The limited detail of related correspondence makes it difficult to establish conclusively the factors driving these attacks. That one manager was targeted twice within 18 months suggests that his behaviour towards slaves might have been especially antagonistic. Nonetheless, as noted above, contemporaries were certain that the hunger then afflicting blacks - to which drought contributed significantly — enhanced the threat that they would turn against their masters. ${ }^{81}$

\section{Government interventions to combat crisis}

The drastic times of the American war period invariably prompted colonial administrators to take drastic measures. In light of Antigua's reliance upon imported supplies, amending the terms of overseas trade was the first recourse of the legislature when shortages commenced. Late in 1775, appeals were made to Craister Greathead, the acting-governor of the Leeward Islands, for provision exports from the colony to be prohibited for 30 days. After receiving approval from the British Colonial Office, the proposal was sanctioned the following June. ${ }^{82}$ A year later, endorsement was obtained for a quite different modification to maritime policy: the legalisation of anti-American piracy. ${ }^{83}$ This came about after a group of 16 Antiguans armed a privately-owned sloop - the aptly-named 'Reprisal'-and began to maraud American shipping in the region. At first, the 16 faced indictment for their action, but subsequent public outcry prompted parliament to condone the practise, leading many other islanders to embark on their own quests of plunder against the enemy. ${ }^{84}$ As discussed earlier, these initial measures, in combination with favourable weather in autumn 1776, ostensibly succeeded in staving off serious shortages for a time. However, with the former serving only while some provision stocks remained, and the latter affording an irregular supply, more cogent action became necessary.

Early in 1776, the governors of British Caribbean colonies were vested with the power to manage severe provision shortages by temporarily authorising imports from non-hostile foreign provinces, provided goods were transported by British vessels. ${ }^{85}$ Reacting to the famine that threatened Antigua and several neighbouring colonies in the summer of 1777,

\footnotetext{
${ }_{78}^{78}$ DD/TD/15/6, M. Walrond to C. Tudway, 18 Apr. 1776; DD/TD/15/6, F. Farley to C. Tudway, 10 Jun. 1778.

${ }^{79}$ CO152/58, Gov. Burt to Lord Germain, 15 Aug. 1778; see also CO152/57, Gov. Burt to Lord Germain, 1 Dec. 1777.

${ }^{80}$ COD/C10, R. Clarke to W. Codrington, 30 Mar. 1780.

${ }^{81}$ A comprehensive assessment of the complex relationships between climate and social unrest is beyond the scope of this paper. For other analyses of the manifold environmental, socio-economic and political factors implicated in slave revolts, see Richard Sheridan, 'The Jamaican slave insurrection scare of 1776 and the American Revolution', The Journal of Negro History 61 (1976): 290-308; Barry Gaspar, Bondmen and rebels, esp. pp. 215-226; Berland, 'Extreme weather and social vulnerability', pp. 225-230.

${ }^{82}$ CO152/55, C. Greathead to Lord Germain, 5 Jun. 1776.

${ }^{83}$ CO152/56, undated Legislative Petition, in letter from T. Warner to C. Greathead, 13 Feb. 1777, Lord Germain to Gov. Burt, 26 Jun. 1777.

${ }^{84}$ CO152/56, Petition of owners of the Reprisal, Jan. 1777; T. Warner to C. Greathead, 14 Jan. 1777; undated legislative petition, in letter from T. Warner to C. Greathead, 13 Feb. 1777; Governor Burt to Lord Germain, 4 May 1777.

${ }^{85}$ CO152/55, C. Greathead to Lord Germain, 5 Jun. 1776.
} 
Governor Burt called for commerce in the Leewards to be liberalised on these terms for six months. The commendation of this step by the British monarch seems to have established something of a precedent; it was repeated in autumn 1778 and again after supplies elsewhere in the region were decimated by the hurricane of October $1780 .{ }^{86}$ Such was the perceived danger on these occasions that trade was even permitted in non-enemy foreign vessels.

By the final years of the 1770s, colonial administrators had to legislate not only for scarcities of vital resources, but also fiscal decline. In response to this, in 1778 and 1779, new taxes were imposed, procedures implemented to expedite the collection of customs duties and additional naval protection granted to commercial shipping. ${ }^{87}$ Yet, by the time the latter policies came into effect, Antigua's interconnected subsistence and credit crisis had climaxed, rousing calls for direct British intervention. After legislators petitioning on three separate occasions for financial and food aid, British officials acquiesced in the final months of 1779. Arrangements were made for bills of exchange totalling $£ 20,000$ (equivalent to roughly $£ 1,257,000$ in modern terms) to be drawn on the royal treasury for the legislature to purchase provisions. These were to be dispensed to planters, who would subsequently pay an unspecified capitation tax on their slaves as a means of reimbursing the Crown. Meanwhile, $£ 17,000$ worth of food, which finally arrived in March 1780, was despatched for subsidised sale. $^{88}$

This was not, however, the last that was heard of the relief package. By May 1783, the colony had managed to settle just $£ 600$ of the combined $£ 37,000$ debt to Britain and, bankrupt once more, had to suspend further repayments. ${ }^{89}$ Neither was 1779 the last time Antiguan administrators sought to allay provision supply problems. To protect the fastdiminishing reserves that had been accumulated in 1780, exports of foodstuffs and wares

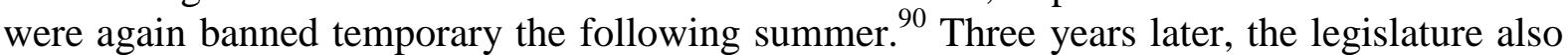
petitioned parliament (unsuccessfully) for St. John's to be given permanent free port status. ${ }^{91}$

\section{Contextualising crisis: the revolutionary period and beyond}

The period of the American Independence War is recorded in the Antiguan archives as one of protracted and multifaceted resource scarcities and agro-economic downturn. The sources attest in clear terms that these difficulties stemmed from the pressures of international conflict and the consequent dislocation of regional trade, coincident with prolonged precipitation deficiency. However, can these contemporary narratives be taken at face value? As noted by colonial historian Richard Sheridan, planters and planter-dominated legislatures in the West Indies may have exaggerated the consequences of warfare and natural disasters in order to protect their interests by securing British aid and convincing slaves of the need to cut rations. This potential caveat is all the more pertinent given that the war coincides with the longest episode of rainfall deficiency in reconstructions of Antiguan precipitation spanning

\footnotetext{
${ }^{86}$ CO152/58, R. Burton to Gov. Burt, 6 Jun. 1778, Lord Germain to Gov. Burt, 9 Jun. 1778; CO152/59, Gov. Burt to Lord Germian, 2 Nov. 1778; CO152/60, Gov. Burt to Lord Germain, 1 Nov. 1780.

${ }^{87}$ CO152/34, Gov. Burt to Board of Trade and Plantations, 6 Jan. 1778; CO152/34, Gov. Burt to Board of Trade and Plantations, 26 Sept. 1779.

${ }^{88} \mathrm{CO} 152 / 59$, undated legislative petition, in letter from Gov. Burt to Germain, 22 Feb. 1779, legislative resolutions, 8 Apr. 1779; undated legislative petition, in letter from T. Jarvis to Gov. Burt, 30 Apr. 1779, undated legislative petition, in letter from Gov. Burt to Germain, 24 May 1779; undated legislative resolutions, in letter from Gov. Burt to Lord Germain, 10 Jun. 1779; Lord Germain to Gov. Burt, 8 Oct. 1779, copy of a minute of the Board of Treasury, 14 Dec. 1779; CO152/34, Gov. Burt to Commission of Trade and Plantations, 13 Jun. 1780; CO152/87, Gov. Lavington to Earl Camden, 30 Jul. 1805.

${ }^{89} \mathrm{CO} 152 / 63$, Gov. Shirley to Lord North, 27 Jul. 1783. When exactly the full balance was settled is unclear, but in 1801 Antiguan officials reported for the first time in three decades that the treasury was in a 'respectable State of Credit'; see CO152/80, Gov. Lavington to Duke of Portland, 23 Feb. 1801.

${ }^{90}$ CO152/61, Gov. Shirley to Lord Germain, 30 Aug. 1781.

${ }^{91}$ CO152/63, undated legislative petition, in letter from Gov. Shirley to Lord Townsend, 15 Apr. 1783.
} 
121 years. $^{92}$ Nevertheless, Sheridan himself, alongside historian Lowell Ragatz, has concluded that there is abundant evidence of exceptional and genuine hardship throughout British Caribbean society at the time. ${ }^{93}$ Such considerations have also been addressed with respect to the Antiguan climate reconstructions, which, it is worth noting, were developed solely on the basis of direct archival references to weather - that is to say, excluding any evidence of the wider environmental and societal impacts of meteorological conditions. These weather references, which originated from a diversity of observers, revealed almost entirely consistent trends over various timescales. ${ }^{94}$ The same point applies to correspondence regarding subsistence and economic difficulties, a considerable proportion of which was private and, thus, unlikely intended to mislead British officials or enslaved people. It is significant that at no point did private accounts conflict with those provided by successive governors of the colony, who were tasked with acting as neutral informants to the Crown (though it should be recognised that they, like much of the political elite, also owned sugar estates). Moreover, the documentation is replete with biophysical indicators of major drought, such as severe water shortages, livestock mortality and wilting vegetation.

Invariably, the unfaithful transmission of information may affect the recording of any episode of disaster. Despite this, the tenor and wealth of contemporary writings leave little doubt that the state of emergency that materialised in late 1770s and early 1780s Antigua was extraordinary in terms of agro-economic decline and human suffering. ${ }^{95}$ A decisive component of this emergency was the occurrence of successive years of deficient rainfall. The disproportionate impacts of consecutive and prolonged phases of extreme weather on pre-industrial colonial societies have been documented extensively in other climate histories. ${ }^{96}$ The present research indicates that the British Caribbean system of nigh-on monoculture was especially vulnerable, with repeated harvest failure capable of pushing the export-reliant economy from a state of reduced profitability to one of universal bankruptcy. Perhaps predictably, in Antigua it was the systematically-deprived slave majority who bore the physical brunt of the resulting austerity and the long-standing neglect of subsistence agriculture. Whites, who were to a great extent buffered by their material wealth, primarily experienced hardship financially. There is evidence, however, that exigencies among slaves posed some threat to elites' very existence, augmenting the potential for servile revolt.

But what of conditions after the war? Despite the strict enforcement of imperial 'Navigation Acts' from 1783, which dictated that provisions from the newly-independent mainland could be transported to the British Caribbean only in colonial shipping, evidence indicates that by the late 1780 s plantations were as well supplied as before the war. ${ }^{97}$ The available sugar production and export data, though discontinuous, suggest a substantial resurgence of plantation operations in Antigua at this time (Figure 3). Contemporary

\footnotetext{
${ }^{92}$ Berland, Metcalfe and Endfield, 'Documentary-derived chronologies of rainfall'; Berland, 'Extreme weather and social vulnerability', chap. 5 .

${ }^{93}$ Sheridan, 'The crisis of slave subsistence': 619-620; Sheridan, 'The Jamaican slave insurrection scare'; Ragatz, The fall of the Planter Class, pp. 142-172;.

${ }^{94}$ Berland, Metcalfe and Endfield, 'Documentary-derived chronologies of rainfall': 1341; Berland, 'Extreme weather and social vulnerability', pp. 73-74. Note that these studies developed two individual rainfall chronologies - one of annual variability throughout Antigua and one of seasonal variability in a specific locality in central-eastern Antigua. These chronologies were based on independent sequences weather references, yet recorded a highly coherent progression of precipitation fluctuations between 1775 and 1783 .

${ }^{95}$ Indeed, systematic examination of diverse Antiguan archival material from 1770-1890 reveals no other discrete episode in which famine and disease culminated in such excessive human mortality in Antigua as during the American war period; see Berland, 'Extreme weather and social vulnerability'.

${ }^{96}$ Davis, Late Victorian holocausts, esp. chaps. 1-2, 4-5; Georgina Enfield, 'Decades of Drought, Years of Hunger: Archival Investigations of Multiple Year Droughts in Late Colonial Chihuahua', Climatic Change 75 (2006): 391-419, esp. 399-403.

${ }^{97}$ Ward, British West Indian Slavery, p. 42.
} 
meteorological conditions are poorly documented, but no instances of major climatic stress are recorded in the archives consulted in this study. It is also suggestive of favourable environmental conditions that one resident planter commented that 'Antigua perhaps never knew successive Years better' than the mid-1780s. ${ }^{98}$

There then ensued another two and a half decades featuring bouts of international conflict and disruptive weather. Initially, these forces did not coincide, however, offering insights into their individual influence over human livelihoods. Prolonged drought returned at a time of peace between 1789 and 1791, reportedly occasioning the decimation of Antiguan subsistence agriculture and livestock, as well as the decline of sugar yields by 'near twothirds' throughout the Leewards. ${ }^{99}$ Notwithstanding these difficulties, there were not the calls of universal bankruptcy that had been so common a decade earlier. Such calls were, however, heard again in the mid-1790s, when debts associated with the French Revolutionary Wars (1792-1802), drought in 1794 and a hurricane in August 1795 prompted local officials to petition the Crown - ultimately unsuccessfully-for a $£ 10,000$ loan. ${ }^{100}$ A similar combination of stresses is documented ten years later. Scanty precipitation, a tropical cyclone in September 1804 and the proclamation of martial law-which suspended agricultural operations for six weeks - resulted in a ruinously small harvest in the summer of 1805 . With the agricultural hiatus costing the colonial treasury $£ 20,000$ and a fleet carrying much of the year's meagre crop captured by the enemy, insolvency had become widespread by July. ${ }^{101}$ Administrators once more solicited a $£ 10,000$ loan, this time successfully. ${ }^{102}$ Records from subsequent episodes of environmental and geopolitical stress are scarce. Nonetheless, a handful of missionaries' letters from 1812, when Britain was at war with Napoleonic France and the United States, are eerily reminiscent of the situation in the late 1770s. In early October, for example, Moravian pastor Joseph Newby wrote:

This year has been a remarkable dry one in this Island[;] this with the American war, makes provisions very scarce \& dear. Both Black \& White [people] feel it severely. Indian corn, the principal food for Negroes \& Stock, is very high in price \& indeed scarcely to be got for money. ${ }^{103}$

Despite commonalities with the late 1700s and early 1800s, records indicate that government responses during the American Revolution period, like the hardships stimulating them, were exceptional. Most significant was the combined $£ 37,000$ worth of aid afforded to Antigua in 1779. Previously, metropolitan intervention of this nature had been rare in the British Caribbean. According to recent climate histories, on just one occasion did Parliament allocate significant funds to disaster relief in the region, providing $£ 20,000$ for the victims of

\footnotetext{
${ }^{98}$ COD/C20, Memorandum of C.B. Codrington, 1790-1792, p.30.

99 Berland, 'Documentary-derived chronologies or rainfall variability': 1337; PA, Vol. 14, p. 444, St. John's diary extract, 21 Jan. 1837; Lanaghan [initials unknown], Antigua and the Antiguans: a full accounts of the colony and its inhabitants from the time of the Caribs to the present day, interspersed with anecdotes and legends, Volume I (London: Saunders and Otley, 1844), p. 189; Oliver, The history of the island of Antigua, p. cxxxviii; John Collins, The case of the sugar colonies (London: publisher unknown, 1792), p. 36; William Young, 'A tour through the several island of Barbadoes, St. Vincent, Antigua, Tobago, and Grenada, in the years 1791 and 1792', in B. Edwards, An historical survey of the island of Saint Domingo together with an account of the maroon negroes in the island of Jamaica; and a History of the war in the West Indies, in 1793, and 1794 (London: publisher unknown, 1801), p. 282.

${ }^{100}$ CO152/77, Petition of W. Hutchinson, 26 Dec. 1795.

${ }^{101}$ CO152/87, Gov. Lavington to Earl Camden, 30 Jul. 1805.

102 CO152/87, Legislative address to Gov. Lavington, 19, 28 Jun. 1805, Earl Camden to Gov. Lavington, 2 Oct. 1805.

${ }^{103}$ OL, Br. J. Newby to Br. Latrobe, 5 Oct. 1812.
} 
a fire in Charleston, South Carolina, in $1740 .{ }^{104}$ The only comparable example in Antigua appears to have been the decision to absolve the colony of paying $£ 2,500$ of royal duties after a hurricane in 1772. ${ }^{105}$ Notably, Britain's vast investment in relief in 1779 may not have stemmed purely from humanitarian concern. In their analyses of the even-more-exceptional $£ 120,000$ grant paid to Barbados and Jamaica after suffering tremendous hurricane damage in 1780, Matthew Mulcahy and Stuart Schwartz suggest that the move was politically motivated; by demonstrating the advantages of subject-hood, it helped to unify Britain and her West Indian possessions and ease criticism of wartime policy at a time of revolutionary sentiment. ${ }^{106}$ To be sure, pressure from the powerful, pro-planter 'West Indian Lobby' in British politics would also have been an important factor. The same considerations could hardly have escaped Members of Parliament when disaster relief for Antigua was being negotiated one year previously. To what extent this earlier action influenced the decisionmaking process behind the Jamaican-Barbadian grant is unclear, but the former was unquestionably an important precursor.

Another institutional response to climate-related dearth that became common during the chaotic late 1700 s and early 1800 s was the temporary liberalisation of trade. Free trade with politically neutral states also had earlier precedents in the British Caribbean, with Jamaica and Dominica having been granted regulated 'free port' status in the $1760 \mathrm{~s} .{ }^{107}$ Yet, there is no evidence - either in the consulted archives or local colonial histories ${ }^{108}$ - of the use of this measure by Antiguan administrators before the American war. Subsequently, it apparently became a standard emergency procedure. The colony was again opened to foreign imports in response to weather-induced shortages in 1789, 1793, 1794 and $1813 .{ }^{109}$ When the legislature sought to enact the procedure in 1793, Governor Burt's admittance of cargoes from foreign territories in the late 1770 s was explicitly cited as a justification. ${ }^{110}$ Measures such as temporarily prohibiting provision exports and legalising acts of piracy against the enemy were also adopted after tropical cyclone strikes in 1785,1812 and $1813 .^{111}$

Notwithstanding the notion that these kinds of government intervention may have been as much about fostering loyalty and appeasing important pressure groups as about reducing hardship, an anti-colonial movement was always unlikely for strategic reasons. As discussed by Andrew O'Shaughnessy, the vast mismatch between the size of the white and black populatiosn of the Lesser Antilles essentially meant that the former was dependent upon a British military presence to preserve their ascendancy in the social order. ${ }^{112}$ Indeed, the existence of both a British garrison and naval dockyard in Antigua may well explain why the intensified misery of local slaves produced no coherent uprising in the colony.

\section{Evaluation and conclusions: Antigua and beyond}

\footnotetext{
${ }^{104}$ Mulcahy, Hurricanes and society, pp. 169-170; Schwartz, Sea of storms, p. 88.

${ }^{105}$ CO152/32, Gov. Payne to Earl of Hillsborough, 18 Sept. 1772, Earl of Hillsborough to Gov. Payne, 9 Dec. 1772. The consulted archives and literature record no other similar occurrence prior to the study period.

${ }^{106}$ Mulcahy, Hurricanes and society, p. 188; Schwartz, Sea of storms, p. 98.

${ }^{107}$ Nadine Hunt, 'Contraband, free ports, and British merchants in the Caribbean World', Diacrone. Studi di Stori Contemporanea 13 (2013): 1.

${ }^{108}$ Lanaghan, Antigua and the Antiguans; Oliver, The history of the island of Antigua; Dyde, A History of Antigua.

${ }^{109}$ CO152/67, J. Nugent to Lord Sydney, 13 Jul. 1789, Gov. Shirley to W. Grenville, 8 Dec. 1789; CO152/73, Gov. Woodley to H. Dundas, 7 Jan. 1793, H. Dundas to gov. Woodley, 24 Feb. 1793; CO152/75, Gov. Stanley to H. Dundas, 11 Jan. 1794, Gov. Stanley to Antiguan Legislature, 11 Jan. 1794; CO152/102, Gov. Elliot to Earl of Bathurst, 15 Aug. 1813, 1 Oct. 1813.

${ }^{110}$ CO152/75, Gov. Stanley to H. Dundas, 31 Dec. 1793, Legislative minutes, 21 Nov. 1793.

${ }^{111}$ CO152/64, Gov. Shirley to Lord Sydney, 1 Oct. 1785; CO152/100, Gov. Elliot to Earl of Bathurst, 12 Oct. 1812; CO152/102, Gov. Elliot to Earl of Bathurst, 15 Aug. 1812.

112 O’Shaughnessy, 'Recoats and slaves': 122-123.
} 
In June 1779, Antigua's battalion of the Royal $60^{\text {th }}$ Regiment remained in peril. Food and water were still scarce, a French invasion seemed imminent and the public treasury was exhausted. Ultimately, we can only speculate at what became of the men, for the surviving documentation is silent on their fate in the year that followed. They would not die in battle, foreign powers launching no direct attack on Antigua during the American war. What is certain is that the hardships endured by the soldiers were far from isolated. Between 1775 and 1783, Antigua was gripped by resource scarcities and economic decline, which, in one way or another, impacted upon all sectors of society. It is possible that the receipt of aid from Britain in late 1779 enabled colonial administrators to remedy the troops' sufferings permanently. More probable, however, is that some infantrymen were among the hundreds of islanders who would succumb to hunger and disease.

The scenario of environmental and geopolitical turmoil was also far from isolated within the Caribbean at large. The literature highlights several other cases in which the troubles of the American war were intensified disastrously by adverse weather. In Barbados, for example, a familiar succession of precipitation scarcity, crop failure and famine unfolded in 1777 and 1778, prompting Britain to despatch food aid to the island. ${ }^{113}$ Meanwhile, remarkably frequent and destructive tropical cyclones during the 1780s-especially in 1780 and 1781 - are understood to have produced considerable regional adversity. ${ }^{114}$ The wider significance of these climatic shocks has been postulated by Schwartz. In late eighteenthcentury parliamentary debates over the amelioration of the conditions of slavery, he notes, some conclusions about slaves' wellbeing were founded upon the abysmal situation observed in the aftermath of the storms. ${ }^{115}$ Antigua may have been spared major cyclone damage at this time, but, in the context of unrelenting drought, circumstances there were likely just as bad as elsewhere. Several studies have proposed that successive climate-related crises in the second half of the 1700s were also pivotal to other political developments in the Caribbean, including the outcome of major military campaigns, rebellions and suspensions of mercantilist trade restrictions. ${ }^{116}$ The present research contributes by illustrating that, at least in Antigua, the American Independence War marked an important watershed in free-trade transforming from a novel and exceptional measure to an established emergency policy. As regards the coordination of humanitarian and economic relief from Britain, it is also apparent that the case of Antigua fitted within a broader framework of colonial crisis management.

Sherry Johnson has highlighted the concurrence of frequent meteorological extremes in this era with a roughly fifty-year global warm anomaly, starting around 1750 during the Little Ice Age (c. 1400-1850). Following on from this, Johnson notes that a recent climate reconstruction exhibits exceptional numbers of El Niño and La Niña cycles in the period 1748-1804-18 of the former and 31 of the latter - which may have resulted in more frequent extreme weather events in the tropical Atlantic. ${ }^{117}$ Such observations have important implications for understanding societal vulnerability in the late eighteenth-century British West Indies. It is evident that recurrent warfare at the time rendered this import-reliant dominion peculiarly susceptible to additional strains on food supplies and finances. If one

\footnotetext{
${ }^{113}$ Sheridan, 'The crisis of slave subsistence': 620.

${ }^{114}$ Ragatz, The fall of the Planter Class, p. 158; Sheridan, 'The crisis of slave subsistence': 625-627; Mulcahy, Hurricanes and society, p. 95 and Chap. 7; Schwartz, Sea of storms, pp. 92-109.

${ }^{115}$ Schwartz, Sea of Storms, 104; Stuart Schwartz, 'Hurricanes and the shaping of circum-Caribbean societies', The Florida Historical Quarterly 83 (2005): 399.

${ }^{116}$ Johnson, 'Climate, community, and commerce'; Sherry Johnson, Climate and catastrophe in Cuba and the Atlantic World; Schwartz, Sea of storms, Chaps. 3-4.

117 Joelle Gergis and Anthony Fowler, 'A history of ENSO events since A.D. 1525: implications for future climate change', Climatic Change 93 (2009): 343-387; cited in Johnson, Climate and catastrophe in Cuba and the Atlantic World, p. 4.
} 
follows Johnson's line of argumentation, it may be that macro-scale atmospheric processes at once made the occurrence of strains of a meteorological nature more probable.

While the present study does not enable a comprehensive evaluation of this suggestion, it has afforded a detailed lens on the dynamics of these converging societal and environmental vulnerabilities within a specific geography. Archival evidence demonstrates that the exigencies experienced in Antigua between 1775 and 1783 cannot be explained solely by the international conflict and trade embargo for which that period is best known. Regional geopolitical and commercial pressures interacted intricately with local nutritional, epidemiological, social and agro-economic circumstances, which deteriorated significantly as a result of drought. High death tolls in other British Caribbean colonies suggest that famine was, perhaps, inevitable with the suspension of trade with the rebelling Thirteen Colonies. Nevertheless, the firsthand accounts of Antiguans leave little doubt that the destruction of subsistence crops by drought contributed considerably to its human cost. Similarly, recurrent failure of sugar harvests, which saw the collapse of public and private finances, resulted from the non-arrival of plantation stores and deficient rainfall. Successive years of climatic stress thus gained special resonance in the highly precarious socio-economic and political milieu in which they unfolded. By exploring the critical role of such natural forces, which have previously received limited scrutiny from historiographers, ${ }^{118}$ this study has sought to shine new light on an otherwise well-studied chapter of the British Caribbean's colonial past.

\section{Acknowledgements}

The research presented here was funded by a three-year doctoral studentship provided by the Faculty of Social Sciences, University of Nottingham. Support from staff at the archives visited for this work and constructive comments from two anonymous reviewers have been greatly appreciated. Special thanks go to Susanne Seymour and Sarah Metcalfe (University of Nottingham) for providing detailed feedback on earlier versions of the paper.

\footnotetext{
${ }^{118}$ E.g. Ragatz, The fall of the Planter Class, p. 158; Sheridan, 'The crisis of slave subsistence': 625-627; Dyde, A History of Antigua, p. 96.
} 